\title{
LAMC2 Gene
}

National Cancer Institute

\section{Source}

National Cancer Institute. LAMC2 Gene. NCI Thesaurus. Code C116275.

This gene plays a role in both extracellular matrix assembly and epidermal development. 